\title{
УДК 681.5
}

Р.В.Казмірчук, С.В.Рижов, О.В.Корольова, В.І. Боженко

Академія сухопутних військ імені гетьмана Петра Сагайдачного, Львів

\section{СВІТОВИЙ ДОСВІД ТА ТЕНДЕНЦІЇ ЗАСТОСУВАННЯ ЗАСОБІВ ІМІТАЦІЙНОГО МОДЕЛЮВАННЯ БОЙОВИХ ДІЙ}

У статті проведено огляд основних принципів та засад застосування засобів імітаційного моделювання, а також висвітлено історію створення, впровадження та новітні тенденції розвитку засобів імітаиійного моделювання для підготовки видів військ (сил) провідних країн світу. Проаналізовано досвід впровадження та подальші перспективи розвитку засобів імітаційного моделювання озброєння, бойової техніки та застосування військових формувань усіх рівнів в загальній системі бойової підготовки Збройних Сил України.

Ключові слова: імітаційне моделювання, симулятор, модель, навчання з використанням імітаційного моделювання, бойові дії.

\section{Вступ}

Постановка проблеми. На сьогоднішній день проблеми підвищення ефективності функціонування різних ланок людської діяльності - у техніці, економіці та багатьох інших, зокрема у військовій справі, вимагають розвитку нових методів досліджень. Імітаційне моделювання (IM) по суті і стало єдиним методом вирішення такого роду задач.

Тому метою даної статті став аналіз основних понять та принципів імітаційного моделювання, досвід та основні тенденції застосування даного дієвого засобу для підготовки та навчання особового складу різних ланок в арміях провідних країн світу та можливості й перспективи його застосування у Збройних Силах України.

\section{Основний матеріал}

Моделювання - це метод рішення задач, при використанні якого досліджувана система замінюється простішим об'єктом, що описує реальну систему і зветься моделлю. Моделювання застосовується у випадках, коли проведення експериментів над реальною системою неможливе або недоцільне: наприклад, внаслідок крихкості або дорожнечі створення прототипу або через довготривалість проведення експерименту в реальному масштабі часу [1].

Розрізняють фізичне i математичне моделювання. Прикладом фізичної моделі $\epsilon$ зменшена копія літака, що продувається у потоці повітря. При використанні математичного моделювання поведінка системи описується за допомогою формул. Особливим видом математичних моделей $є$ імітаційні моделі.
Етапи процесу побудови моделі складної системи:

1. Формулюються основні питання про поведінку системи, відповіді на які ми хочемо отримати за допомогою моделі.

2. 3 безлічі законів та керунків поведінкою системи вибираються ті, вплив яких є істотним при пошуку відповідей на поставлені питання.

3. У доповнення до цих законів, за


частин формулюються певні гіпотези функціонування.

Критерієм адекватності моделі служить практика.

Реалізується модель по наступних етапах:

1. Як i раніше, формулюються основні питання про поведінку складної системи, відповіді на які ми хочемо отримати.

2. Здійснюється декомпозиція системи на простіші частини-блоки.

3. Формулюються закони i «правдоподібні» гіпотези щодо поведінки як системи в цілому, так і окремих $\dddot{11}$ частин.

4. Залежно від поставлених перед дослідником питань вводиться т.зв. «системний час», що моделює хід часу у реальній системі.

5. Формалізованим чином задаються необхідні феноменологічні властивості системи і їі окремі частини.

6. Випадковим параметрам, що фігурують у моделі, ставляться у відповідність деякі їх реалізації, що лишаються постійними протягом одного або декількох тактів системного часу. Далі відшукуються нові реалізації.

Імітаційна модель - це комп'ютерна програма, яка описує структуру і відтворює поведінку реальної 
системи у часі. Імітаційна модель дозволяє отримувати докладну статистику про різні аспекти функціонування системи залежно від вхідних даних.

Імітаційне моделювання застосовується до процесів, в хід яких може час від часу втручатися людська воля. Людина, яка керує операцією, може, залежно від обстановки, що склалася, ухвалювати ті або інші рішення, подібно до того, як шахіст, дивлячись на дошку, вибирає свій черговий хід. Потім очікується зміна обстановки у відповідь на це рішення і до яких наслідків воно призведе за деякий час. Наступне поточне рішення ухвалюється вже 3 урахуванням реальної нової обстановки і т.д.

В результаті багаторазового повторення такої процедури людина набуває досвіду, вчиться на своїх i чужих помилках і поступово починає набувати навички у прийнятті рішень (рис. 1).

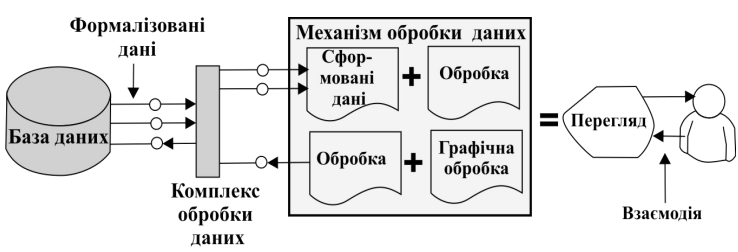

Рuc. 1. Схема взаємодії «імітаційна модель - людина»

Мета імітаційного моделювання полягає у відтворенні поведінки досліджуваної системи на основі результатів аналізу найбільш істотних взаємозв'язків між іiі елементами або, інакше кажучи, - розробці симулятора досліджуваної наочної області для проведення різних експериментів.

Імітаційне моделювання дозволяє відтворювати поведінку системи в часі. Перевагою $є$ те, що часом у моделі можна керувати: уповільнювати у випадку швидкоплинних процесів та прискорювати для моделювання систем $з$ повільною динамікою [2].

Машинна імітація в усьому світі набула значного поширення при дослідженні складних систем завдяки важливим перевагам, що їх мають користувачі цього методу:

1. Виникає можливість відповісти на багато запитань, що постають на ранніх стадіях задуму і попереднього проектування систем, уникнувши застосування методу спроб і помилок, пов'язаного із значними витратами.

2. Метод дає змогу досліджувати особливості функціонування системи за будь-яких умов, зокрема й тих, які не реалізовані у натурних експериментах. При цьому параметри системи i навколишнього середовища можна варіювати у надзвичайно широких межах, відтворюючи довільну обстановку.

3. Стає можливим прогнозувати поведінку системи у близькому та у віддаленому майбутньому, екстраполюючи на моделі результати натурних випробувань. У такому разі дані, зібрані раніше, поповнюються завдяки застосуванню статистичного підходу.

4. Імітаційні моделі технічних і технологічних систем та пристроїв дають змогу у багато разів скоротити час їх випробування.

5. За допомогою методу машинної імітації можна штучним чином швидко та у великому обсязі отримати потрібну інформацію, що відображає хід реальних процесів, уникнувши дорогих, а часто й неможливих випробувань цих процесів у реальному середовищі.

6. Імітаційна модель $€$ надзвичайно гнучким пізнавальним інструментом, здатним відтворювати будь-які реальні та гіпотетичні ситуації.

7. 3'являється можливість моделювати i програвати «аварійні» ситуації, що $є$ унікальною властивістю цього методу навчання.

8. Виникає можливість повторювати експеримент довільну кількість разів, що дозволяє формувати у користувачів стійкі навички правильних дій у характерних випадках.

Для найбільш розвинених країн світу, таких, як США, Австралія, Великобританія, Франція імітаційне моделювання бойових дій стало потужним інструментом, який надає можливість здійснювати оперативну підготовку органів управління в динамічних умовах, максимально наближених до бойових. Воно дозволяє виконувати тренування багато разів і при цьому уникнути застосування підпорядкованих сил та засобів, що у кінцевому підсумку веде до скорочення витрат на проведення заходів оперативної підготовки та запобігання втрат особового складу та пошкодження озброєння та військової техніки (рис. 2).

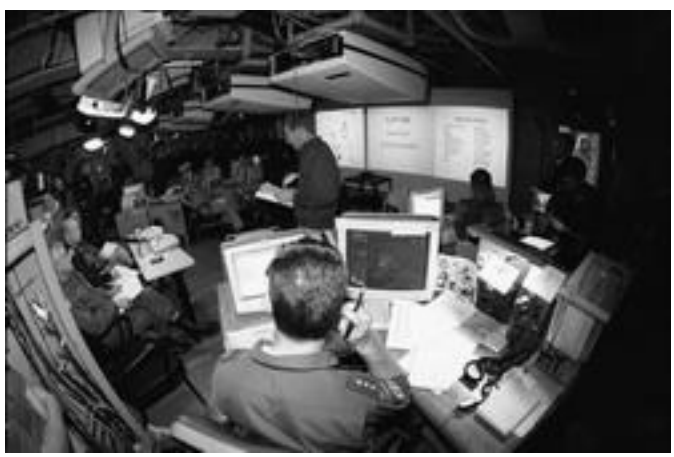

Рuc. 2. Проведення тренувань за допомогою засобів імітаційного моделювання

\section{Застосування засобів імітаційного моделювання бойових дій у США}

Розвиток засобів імітаційного моделювання у США та їх застосування у військовій сфері розпочалися практично із початком розвитку засобів обчислювальної техніки. Вже у середині 1970-х років створена у складі Міністерства оборони США 
Лабораторія імітації конфліктів розробила реалістичне програмне забезпечення для імітації бойових дій.

Наприкінці 1970-х рp. була розроблена програма «Янус» - перша, в якій був використаний графічний інтерфейс. Вона застосовувалась у плануванні бойових дій у Панамі, на Середньому Сході, у Сомалі, Боснії та інших міжнародних конфліктних ситуаціях.

У 1997 р. було створено найпотужнішу програму «Лівермо», що об'єднала та підсилила можливості двох попередніх програм - «Об'єднаної конфліктної моделі» (покращеної версії «Янус») та «Об'єднаного тактичного імітатора».

1999 р. - система JCATS (Joint Conflict snd Tactical Simulation) використовувалася для репетицій майбутніх бойових операцій у конфлікті в Косово, а також для морської піхоти та ВМС США для планування та участі у навчаннях на території Сан-Франциско. Під час навчань програма JCATS аналізувала дії фахівців та тестувала в реальному часі ефективність повітряної та артилерійської атак (рис. 3).
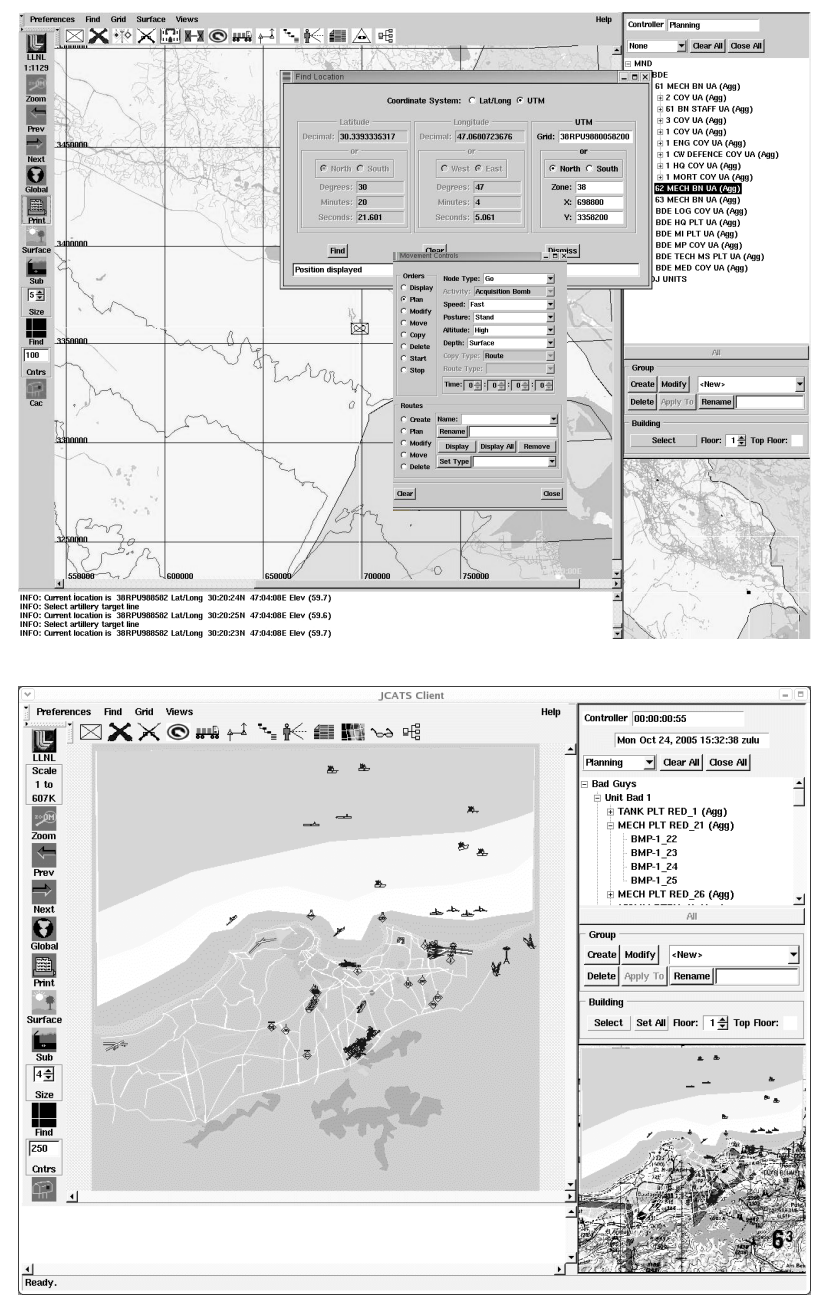

Puc. 3. Графічний інтерфейс програми JCATS
Сьогодні США проводять підготовку за двома 3 трьох основних програм Міністерства оборони 3 Підготовки і трансформації: Національної програми підготовки ведення спільних операцій та Програмою розвитку наукових досягнень. Третьою основною програмою $є$ Програма спільного оцінювання, що здійснюється під керівництвом Відділу 3 управління персоналом та готовності Міністерства оборони.

Національна підготовка 3 ведення спільних операцій передбачає використання дійсних, віртуальних та вигаданих моделей і тренажерів в межах інтегрованої мережі, що складається 330 постійних тренувальних центрів для забезпечення виконання завдань 3 ведення спільних операцій в найбільш реальних умовах. Програма забезпечує посилену підготовку для ведення спільних операцій за допомогою використання широкого спектру дійсного, віртуального та вигаданого навчального середовища.

Окрім цього, ця програма забезпечує підготовку та акредитовану підтримку в загальному 700 військовослужбовців щорічно у 20 штатах. Завданням даної програми на тривалий термін $€$ об'єднання родів військ та служб, посередників та багатонаціональних компонентів партнерів коаліції для проведення операцій [3].

У 2007 p. Австралія підключилася до об'єднаного національного центру навчання США через спеціально створений спільний комплексний навчальний центр, розташований коло Сіднею. Сучасні засоби зв'язку забезпечують зв'язок оборонних сил Австралії з американськими силами та можливість проводити спільні навчання на базі моделювання. Таке моделювання можна корегувати 24 години на добу, сім днів на тиждень. Такий підхід збройних сил Австралії спрямований на підвищення боєготовності та взаємозв'язку між США та Австралією, а також сприяє інтеграції натурних, віртуальних та конструктивних технологій навчання.

\section{Застосування засобів імітаційного моделювання у збройних силах країн Європейської співдружності}

Сьогодні IM у країнах - учасницях НАТО застосовується для тренування особового та командного складу в опануванні тактикою дій та навичок застосування ресурсів, аналізі ефективності зброї та різноманітних силових структур, плануванні та репетиціях поставлених завдань. Крім військових сценаріїв, IM імітує вправи щодо боротьби 3 розповсюдженням наркотиків, подолання наслідків катастроф, миротворчої 
діяльності, антитерористичних заходів, захоплення заручників, охорони об'єктів.

Оскільки за результатами соціологічних досліджень прогнозується, що до 2010 р. 75\% населення світу буде проживати в умовах міст, то стає очевидним, що великі міста у XXI сторіччі будуть найбільш ймовірними аренами бойових дій. Тому у Європі відкрито кілька сучасних центрів бойової підготовки, що спеціалізуються на мобільних операціях в умовах урбаністичного середовища.

У ЗС Франції 2007 році для підготовки військових управлінців високого рівня було створено Центр імітаційного моделювання для навчання, тренування i експериментів (CSFEE). Його розвиток проходить в рамках державної програми MENTOR. Даний центр використовується для підготовки штабів стратегічного рівня в рамках навчань CMX (Crisis Management Exercises) та штабів оперативного рівня в ході навчань САХ (Computer Assisted Exercises).

У рамках програми MENTOR буде розвиватися ще один програмний продукт під назвою ALLIANCE, який забезпечуватиме можливості проведення міжнародних навчань.

Оперативне командування сухопутних військ 3С Франції (СFАТ) теж використовує низку програмних продуктів, частина 3 яких має можливості імітаційного моделювання бойових дій. На рівні командування сухопутним компонентом певної операції застосовується програма НАТО TOPFAS (Tool for Operational Planning, Force Activation and Simulation), що допомагає пришвидшити підготовку оперативних документів планування операції (документи брифінгів з аналізу операції та прийняття рішення, концепцію та план операції, бойові накази різного рівня). Результати роботи 3 даним програмним продуктом використовуються іншими програмами, такими як ADAMS (Allied Deployment and Movement System), що призначена для координації висування та розгортання багатонаціональних сил. Під дані програми розроблені бази даних реальних військових формувань, які дозволяють проводити необхідні розрахунки.

CFAT також провело експеримент 3 програмою APLET, що має модуль імітаційного моделювання бойових дій та призначена для допомоги командиру рівня дивізії (бригади) у прийнятті рішення на операцію. Програма має можливість моделювати результати бою з противником за різних варіантів побудови бойового порядку та вибору способу дій як своїх військ, так i противника. Результати розрахунків 3 програванням усіх вірогідних варіантів можуть бути виведені на екран.
Відтворення ведеться у прискореному режимі. Програма дещо схожа на комерційну комп'ютерну гру, проте надає командирові необхідні дані для прийняття рішення.

Навчання із застосуванням засобів імітаційного моделювання батальйонного, бригадного та вищого рівня включені до загальної системи бойової підготовки збройних сил.

Розвиток програмного забезпечення імітаційного моделювання йде в напрямку найбільш повної імітації всіх функцій застосування озброєння, бойової техніки та військових формувань.

Найбільш динамічним сектором імітаційного моделювання є розвиток програм, що допомагають командирам різного рівня у прийнятті рішення на бій (операцію). Такі програмні продукти поряд із наданням можливостей редагування бойових графічних та текстуальних документів мають також модуль імітаційного моделювання, який дозволяє співставити обрані способи дій військ своїх та супротивника, а також, прорахувавши декілька варіантів ведення бою, вибрати найкращий [4].

Навчити підрозділи взаємодії і тактиці під час бойових операцій покликані системи іншого класу. Вони являють собою комбінацію тактичних імітаторів бойових дій на мапі (коли користувач лише сидить перед монітором) і симуляторів військової техніки (коли військовослужбовець знаходиться на полі бою). Однією 3 найвідоміших стала Британська CATT (Combined Arms Tactical Trainer) - Тактичний тренажер із використанням різноманітної зброї.

Електронний комплекс дозволяє вдосконалювати тактику ведення бою до 700 військовослужбовців одночасно. У САТТ об'єднані у мережу симулятори різноманітної бронетехніки: бойових танків Challenger, БМП Warrior, легких танків Scimitar. Комплекс використовується для тренувань усіх військовослужбовців - від окремих рядових до командирів бригад, що відповідають за сотні життів. Після проведення таких навчань командири разом 3 підлеглими переглядають відтворений комп'ютером хід бою і визначають свої помилки.

На моніторі «гравці» бачать реалістичний ландшафт i можуть битися як із супротивником, генерованим комп'ютером, так i проти комп'ютерних підрозділів, якими керують їхні колеги - умовні противники. Командири планують та спостерігають за ходом битви у симуляторах командно-спостережних пунктів (КСП) (рис. 4) .

Піхотинці можуть залишати симулятор КСП і переходити у піхотний симулятор, щоб діяти у пішому порядку, так, як це відбувалося б в умовах реального бою. Щоб досягти максимальної 
ефективності, система сконструйована так, щоб давати найбільш реалістичну картину. Наприклад, двигуни перегріваються, якщо їх надовго залишити працювати вхолосту; якщо бронетехніка пошкоджена, необхідний ремонт, потрібні боєприпаси тощо. Бій ведеться за різних погодних умов і проти різної військової техніки, яка $є$ на озброєнні країн світу.


Рис. 4. Вигляд приміщень центру імітаційного моделювання

На початку 2007 p. BAE System (Великобританія) випустила нову навчальну систему TERRIER, що характеризується передовою технологією 3 гнучким зворотнім зв'язком. Ця система пропонує всебічний, економічний та екологічно нешкідливий підхід до навчання військовослужбовців. На початку 2006 р. ця компанія уклала контракт 3 оборонним відомством на поставку двох систем TERRIER [5].

B голландському містечку Марнехузен (Нідерланди) знаходиться найбільший центр спеціалізованої підготовки в Європі, що займає площу 1500 га. Центр широко використовується силами НАТО, там встановлене навчальне обладнанням, що моделює реальні умови. Системи навчання фірми Saab передбачають також використання обладнання для сил протидії, які ведуть операції в умовах міста.
У 140 км на північ від столиці Норвегії м. Осло у 2004 р. відкрито армійський центр навчання. Він повністю оснащений спеціальною апаратурою та забезпечує натурне ведення вогню при мобільних операціях в межах міста, форсування водних перешкод та дії на злітному полі. Такі засоби забезпечують реалістичне навчання 3 натурним веденням вогню 3 усіх типів систем озброєння, навчання сучасним методам маневру та спільному навчанню взаємодії з підрозділами, озброєними стрілецькою зброєю, артилерією а також авіаційною та вертолітною підтримкою.

Завдання учбово-тренувального центру армії Норвегії полягає у тому, щоб навчати підрозділи армії у відповідності із доктриною тактики аналізу прийомів ведення бою, що включає в себе підготовку, орієнтовану на виконання бойової задачі, на підготовку особового складу до рівня бригади, підготовку для роботи 3 основними системами озброєння.

Сучасні системи навчання центру підготовки включають тренажери на базі комп'ютерів, тренажери на базі відеотехніки для робіт 3 технічного обслуговування на башті та закритий лазерний далекомір для наводчиків. Все це обладнання знаходиться в одному центральному приміщенні (рис. 5), в той час як один сучасний зовнішній далекомір, комплексний бойовий тренажер та командно-штабний тренажер для навчання підрозділу розташовано поблизу бойового центру підготовки.

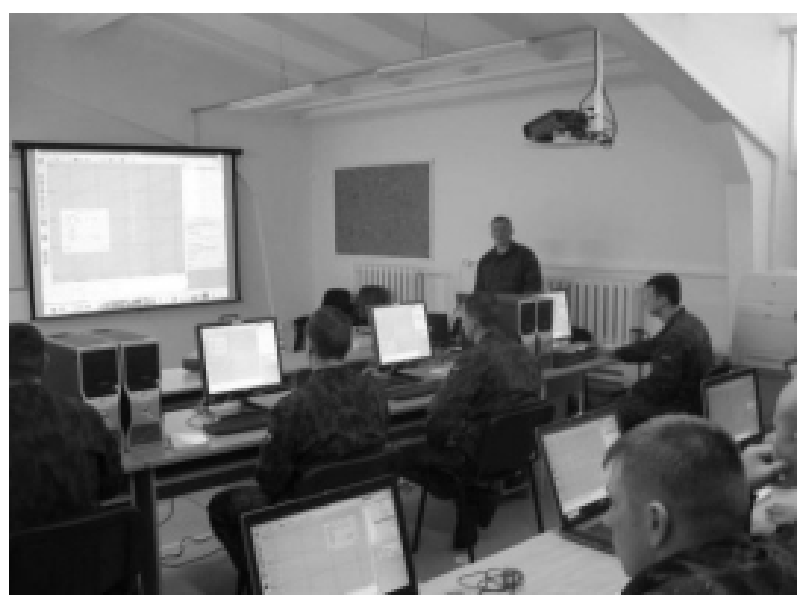

Рис. 5. Вигляд приміщення 3 командно-штабним тренажером

Основним центральним стрижнем контракту фірми Saab $є$ постачання обладнання, технічне обслуговування та технічна підтримка тренажерів, які забезпечують реальну картину для всіх видів навчання та контроль за виконанням вправ. Це дає можливість використання необхідних засобів для планування та підготовки навчання, аналізу та оцінки. 
Найближчий сусід Норвегії Фінляндія, яка не входить до союзу НАТО, також розробляє бойовий центр підготовки. Норвегія, Швеція, Фінляндія, Естонія, а також, можливо, Ірландія сформують 5-ту європейську бойову групу 311 груп, що заплановані. На першому етапі чисельний склад скандинавської бойової групи складатиме близько 2400 офіцерів та солдат $(2000,200,150$ та 50 військовослужбовців зі Швеції, Фінляндії, Норвегії та Естонії відповідно).

У 2002 р. фірма Saab Training Systems уклала контракт на постачання обладнання комп'ютерного моделювання та підтримку програми навчань.

Центр Розвитку та Освіти фінського національного оборонного коледжу тісно взаємодіє 3 навчальною бригадою Pori та розробляє спільні програми навчання майбутнього для фінських збройних сил у співробітництві із силами НАТО та промисловими підприємствами, серед яких $є \mathrm{Saab}$, CAE і фінська компанія Insta.

Фінляндія також бере участь у серії навчань Viking на території Швеції. У шведському центрі військових ігор проходять підготовку сили коаліційних військ чисельністю близько 50000 осіб. Навчання Viking'08 на базі Internet використовувало конструктивну систему моделювання виробництва фірми BAE Systems та портативну ігрову систему виробництва фірми Saab.

Слід зазначити, що Швейцарія зберігає свій нейтральний статус. Проте армія Швейцарії брала участь у миротворчих силах у Боснії у складі Організації з безпеки та співробітництва у Європі та у складі спостережної комісії нейтральних держав у Південній Кореї. Центр підготовки та навчання сухопутних військ Швейцарії розташований у 75 км на південь-схід від Цюріха. Це сучасний військовий навчальний комплекс 3 декількома багатоповерховими будинками постійної будівлі. Цей бойовий центр підготовки повністю обладнаний апаратурою супроводу, звуковими та візуальними засобами і системами з факторами вражаючої дії озброєння.

Усі системи, установлені в навчальному центрі підготовки, виготовлені, поставлені та встановлені за участі фірм RUAG Electronics та RUAG COEL. Вони включають комбіновану систему прямого наведення озброєння на ціль та проведення практичних занять зі зброєю у зоні операції із зовнішнім керуванням.

На даний момент швейцарський бойовий центр підготовки та навчання у м. Валенштадт знаходиться на етапі випробувань та аналізу. Устаткування вже поставлене, але оскільки його придбання пов'язане із значними фінансовими витратами із засобів, що виділяються міністерством оборони Швейцарії, його встановлення буде знаходитись під постійним контролем міністерства оборони. Цей проект забезпечить базову підготовку для тактичного застосування піхотного озброєння та може бути повністю інтегрований у бойовий центр підготовки, розташований у містечку Майлу у 200 км на схід від Парижу [6].

\section{Російська Федерація}

На сьогоднішній день розроблені для Міністерства оборони РФ автоматизована система моделювання бойових дій (АСМБД) [7] та багатофункціональний комплекс моделювання бойових дій (КМБД) протиповітряної оборони та військово-повітряних сил Росії [8] призначені для оцінки ефективності ведення бойових дій шляхом повторення за допомогою електроннообчислювальних машин (ЕОМ) двохсторонньої динаміки збройної боротьби оперативного та оперативно-тактичного рівнів (рис. 6-7).



Рис. 6. Робоче вікно програми АСМБД

Програмні засоби АСМБД та КМБД дозволяють моделювати:

- одиночні підводні човни, що діють самостійно;

- надводні кораблі;

- літальні апарати;

- тактичні групи;

- оперативно-тактичні й тактичні угруповання, що діють у похідних, бойових порядках і бойовому строю;

- пункти базування;

- командні пункти;

- об'єкти зв'язку;

- космічну систему розвідки та цілевказання;

- стаціонарну систему спостереження;

- систему РЛЗ виявлення повітряних і надводних цілей; 
- систему ЗРК континентальної ППО;

- систему зв'язку.

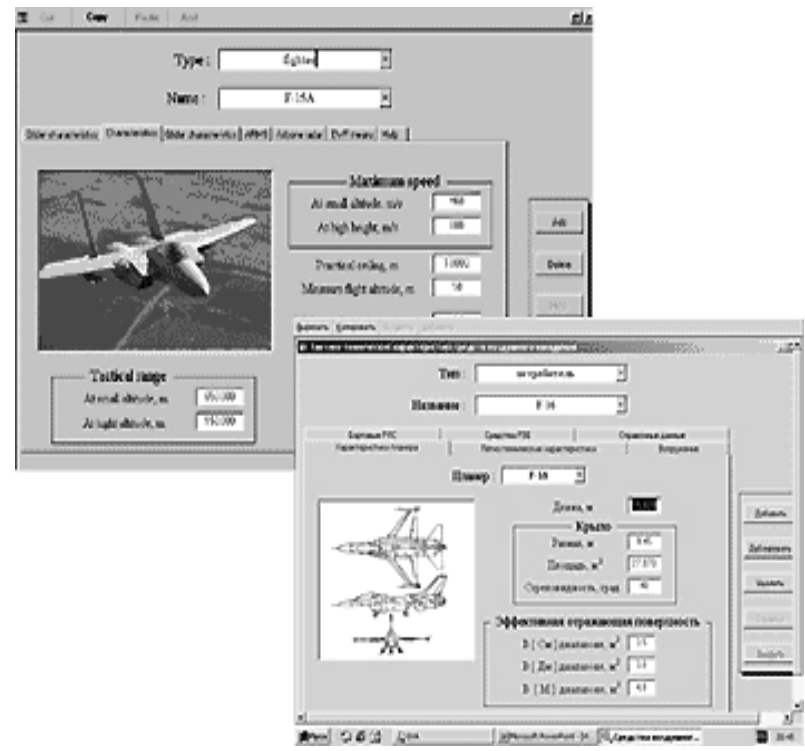

Pис. 7. Робоче вікно програми КМБД

Математично описані та відтворені на EOM наступні фізичні та інформаційні процеси, властиві збройній боротьбі:

- просторове переміщення маневрених об'єктів сил сторін;

- розв'язок об'єктами поставлених перед ними завдань;

- пошук, відхилення від виявлення, встановлення взаємних контактів;

- спостереження, видача даних наведення та цілевказання, наведення об'єктів;

- добування інформації об'єктами сторін;

- приймання-передача інформації об'єктами сторін;

- збір та узагальнення інформації про обстановку на командних пунктах системи керування об'єктами сторін;

- ураження об’єктів та зміна рівня їх функціонування;

- відбиття нападу супротивника, нанесення ударів, виконання атак, участь в бойових діях;

- передача наказів, розпоряджень силам, формування повідомлень за результатами дій сил;

- проведення забезпечувальних дій і заходів.

АСМБД та КМБД призначені для забезпечення діяльності органів керування при розв'язку наступних завдань:

- завчасне планування операцій бойових дій, оперативних об'єднань та угруповань різнорідних сил;

- проведення оперативно-тактичних досліджень;

- підготовка та проведення оперативних односторонніх командно-штабних навчань (ОКШУ) на картах і військових ігор;
- підготовка та проведення двосторонніх ОКШУ 3 визначеними силами.

Основні функції комплексів:

- Покрокове (із заданою дискретністю часу) імітаційне моделювання фізичних і інформаційних процесів, властивих збройним силам.

- Розрахунки чисельних показників ефективності дій сил ворогуючих сторін на кожний момент часу.

- Графічне відображення ходу розвитку процесів, що моделюються в умовних позначках, прийнятих при оформленні бойових документів, на тлі модельованого театру воєнних дій.

- Розподіл інформації про обстановку, що моделюються, та розмежування доступу до інформаційних ресурсів комплексу між учасниками моделювання (офіцерами-операторами) відповідно до встановлених повноважень.

\section{Розвиток засобів імітаційного моделювання у ЗС України}

Вітчизняне імітаційне моделювання, як новий науковий напрямок, почало інтенсивно розвиватися наприкінці 60-Х рp., коли стали широко впроваджуватися та використовуватися складні технічні системи у найрізноманітніших галузях людської діяльності (космос, бойові дії, транспорт, біологія, медицина, економіка, нові технології на виробництві й ін.).

Велися розробки й дослідження 3 різних напрямків в царині імітаційного моделювання:

- розвиток методології, методів і технологій моделювання;

- розробка засобів і систем моделювання на базі універсальних алгоритмічних мов моделювання;

- розробка пакетів моделювання широкого призначення;

- розробка проблемно-орієнтованих пакетів моделювання.

Імітаційне моделювання застосовувалося при розв'язку завдань радіолокації, протиповітряної оборони, розв'язку завдань аналізу та розподілу ресурсів.

Закономірно, що розробники засобів і систем імітаційного моделювання в Україні використовували закордонний досвід розробки таких систем.

Історія становлення й розвитку імітаційного моделювання в Україні пов'язана 3 відповідними етапами у світовій практиці.

Етап 1 (1955-1960). Програми для завдань моделювання розроблялися на основі таких загальновідомих універсальних мов, як FORTRAN та ALGOL. 
Етап 2 (1961-1965). 3'явилися перші мови моделювання: GPSS, SIMSCRIPT, SIMULA, CSL, SOL. Була розроблена так звана «концепція погляду на світ» (world view).

Етап 3 (1965-1970). 3'явилося друге покоління мов моделювання GPSS V, SIMSCRIPT II.5, SIMULA 67.

Етап 4 (1971-1978). Розвиток вже розроблених мов i засобів моделювання, орієнтований насамперед на підвищення ефективності процесів моделювання та перетворення моделювання у більш простий i швидкий метод дослідження складних систем.

Етап 5 (1979-1984). Роки переходу від програмування до розвитку моделей. Основний акцент було перенесено на ідентифікацію інтегрованих засобів імітаційного моделювання.

Процес моделювання включає такі етапи, як створення моделі, програмування, проведення імітаційних експериментів, обробку та інтерпретацію результатів моделювання. Однак традиційна перевага віддавалася етапу програмування. Така схема моделювання багато в чому повторює схему проведення натурних випробувань і зводиться лише до імітації траєкторій вивчених моделей.

3 появою імітаційних моделей змінилася концепція моделювання, яка тепер розглядається як єдиний процес побудови та дослідження моделей, що має програмну підтримку. Тепер головним стає формальне поняття моделі, яке не лише пояснює динаміку системи, але є предметом математичних досліджень. Стає можливим достовірний аналіз багатьох практично важливих властивостей моделі (стаціонарних розподілів, малих ймовірностей, чутливості, надійності й вірогідності результатів моделювання). Ці властивості особливо істотні при дослідженні високовідповідальних та великомасштабних систем, де ціна помилки особливо висока.

Етап 6 (1985-1994). Перенесення програмного забезпечення для імітаційного моделювання на персональні ЕОМ 3 використанням засобів графічного інтерфейсу (для візуалізації та анімації процесів моделювання).

Етап 7 (1995-1998). Розробка засобів технологічної підтримки процесів розподіленого імітаційного моделювання на мультипроцесорних EOM і мережах.

Україна має більш ніж 25-річний досвід розробки та впровадження у різних ужиткових галузях засобів та систем імітаційного моделювання. Велика географія впроваджень свідчить про значний вплив зазначених розробок на рішення таких загальнодержавних і національних проблем, як:
- прийняття відповідальних проектних рішень у різних сферах людської;

- підготовка та навчання наукових і науковотехнічних фахівців найбільш сучасним інструментам досліджень на базі ЕОМ;

- накопичення та використання досвіду досліджень у різних прикладних областях у стандартній для всіх користувачів і дослідників формі.

На сьогоднішній день в Україні почато цикл робіт по створенню засобів і систем розподіленого імітаційного моделювання на платформі сучасних EOM та операційних систем. Досвід застосування імітаційного моделювання інших країн планується повною мірою застосовувати й в Україні.

Використання імітаційного моделювання значно розширює можливості ЗС України щодо відпрацювання питань взаємодії 3 оборонними відомствами країн найближчого оточення та країнпартнерів.

Створення центрів імітаційного моделювання у Збройних Силах України, що вже знаходяться в процесі своєї реалізації, дасть змогу системного проведення комп'ютерних навчань зі штабами бригад та інших військових формувань [9].

Одним 3 кроків в бік інтегрування імітаційного моделювання у процес оперативної і бойової підготовки Збройних Сил України є приєднання до одного 3 перспективних проектів в цій галузі проекту SEESIM (Південно-східноєвропейського мережного моделювання). Проект SEESIM є однією 3 основних ініціатив, що реалізуються в рамках діяльності Ради міністрів оборони країн Південносхідної Європи (SEDM) за підтримки об'єднаного командування США в Європі. Навчальними цілями проекту SEESIM визначені:

- відпрацювання процедур взаємодії органів державного та військового управління під час виникнення надзвичайних ситуацій та загрозі скоєння терористичних актів;

- тренування персоналу органів державного та військового управління;

- відпрацювання процедур оповіщення під час виникнення надзвичайних та кризових ситуацій;

- перевірка функціонування всіх наявних засобів зв'язку, включаючи комерційні телефонні та факсимільні лінії зв'язку, Інтернет, PIMS тощо.

В рамках проекту один раз на два роки проводяться комп'ютерні командно-штабні навчання «SEESIM» на територіях семи країнучасниць.

Іншим шляхом інтегрування імітаційного моделювання у процес оперативної і бойової підготовки Збройних Сил України є збільшення питомої ваги учасників з українського боку у 
щорічних навчаннях 3 використанням ресурсів імітаційного моделювання «Rapid Trident» (участь у міжнародній миротворчій операції з встановлення миру). Основною метою цього навчання $\epsilon$ поліпшення сумісності між штабами та підрозділами країн-учасниць навчання, практичне використання досвіду, отриманого в миротворчих операціях та попередніх навчаннях, підвищення рівня взаєморозуміння та співробітництва між військовослужбовцями різних країн.

Істотним кроком впровадження імітаційного моделювання у процес бойової та оперативної підготовки стане розробка та проведення міжвідомчого, за участю представників МВС, МНC, ДПСУ, СБУ, командно-штабного навчання 3 використанням ресурсів імітаційного моделювання.

У відповідності до оборонних завдань, які покладені на ЗС України щодо виконання завдань у районах надзвичайних ситуацій природного та техногенного характеру, в тому числі в умовах правового режиму надзвичайного стану, від ЗС України можуть залучатись органи управління та військові частини Об'єднаних сил швидкого реагування. Участь у проведенні таких навчань допоможе не лише відпрацювати питання процедур взаємодії між відомствами, а й виявити в ході навчання такі проблемні питання, які не можливо передбачити в ході підготовки до виконання цих завдань.

На сьогоднішній день вже створений та функціонує центральний елемент системи імітаційного моделювання ЗС України - Центр імітаційного моделювання кафедри інформатизації штабів Національної академії оборони України, де встановлена американська система JCATS. Програма являє собою імітатор конфліктних ситуацій на землі, у повітрі й на морі, що можуть розв'язуватися на рівні як окремого солдата, так i корпусу швидкого реагування чисельністю до 5 тис. осіб. Комп'ютерна мережа розгорнута у 12 навчальних аудиторіях. Одночасно у цій мережі можуть працювати 179 військовослужбовців. Оперативна ситуація, що моделюється, $\epsilon$ максимально наближеною до реальної: прораховуються сотні параметрів до найдрібніших деталей: місцевості, окремо схеми кожного будинку, стану шляхів, погодних умов, тривалості світлового дня, використання різноманітної зброї і систем наведення [10].

Подальший розвиток передбачає створення подібних центрів у всіх видових інститутах та об'єднання їх у єдину мережу моделювання UASIMNET (Мережа імітаційного моделювання 3C України) (рис. 8). Це створить умови для проведення масштабних розподілених командно- штабних навчань 3 використанням ресурсів імітаційного моделювання, участь в яких одночасно можуть брати як штаб армійського корпусу, так й визначені штаби підпорядкованих бригад, що створює унікальні умови для відпрацювання питань злагодження штабів різних ланок [11].



Рис. 8. Проект мережі імітаційного моделювання ЗС України UASIMNET

Таким чином, зазначені шляхи інтегрування імітаційного моделювання в процес оперативної і бойової підготовки Збройних Сил України дозволять:

- д досягнути якісно нового іiі рівня;

- залучити до оперативної підготовки більшу кількість з'єднань та частин;

- запобігти втрат у особовому складі, завдання шкоди навколишньому середовищу та значних витрат на підготовку та проведення навчань iз органами управління з'єднань Збройних Сил України.

\section{Висновки}

Загалом можна констатувати, що сектор імітаційного моделювання у збройних силах провідних країн світу займає визначне місце у системі підготовки військ (сил). Навчання із застосуванням засобів імітаційного моделювання батальйонного, бригадного та вищого рівня включені в загальну систему бойової підготовки збройних сил. Розвиток спеціального програмного та математичного забезпечення імітаційного моделювання йде в напрямку найбільш повної імітації всіх функцій застосування озброєння, бойової техніки та військових формувань.

Найбільш динамічним сектором імітаційного моделювання є розвиток програм, що допомагають командирам різного рівня у прийнятті рішення на бій (операцію). Такі програмні продукти, поряд із наданням можливостей редагування бойових графічних та текстуальних документів, мають також модуль імітаційного моделювання, який дозволяє співставити обрані способи дій своїх військ та 
противника та, прорахувавши декілька варіантів ведення бою, вибрати оптимальний.

Досвід застосування імітаційного моделювання в арміях провідних країн світу може повною мірою бути застосований i в Україні. Обладнаний у Національній академії оборони України Центр імітаційного моделювання дозволяє проводити повноцінні комп’ютерні навчання зі штабами бригад та армійських корпусів. Проте, в більшості випадків, Центр проводить багатонаціональні навчання лише 3 частковим залученням українських офіцерів.

Створення пересувного центру імітаційного моделювання Сухопутних військ Збройних Сил України дало змогу реалізувати концепцію системного проведення комп'ютерних навчань із штабами бригад та інших військових формувань Сухопутних військ.

Але досвід проведення таких навчань у збройних силах провідних країн світу, особливо стосовно методики їх планування, розробки необхідних баз даних, проведення, розбору та аналізу результатів навчання для української сторони був би дуже корисним. Тому створення в Збройних Силах України імітаційного центру тактичної підготовки - нагальне та актуальне завдання сьогодення.

\section{Список літератури}

1. Шеннон Р. Имитачионное моделирование систем - искусство и наука / Р. Шеннон. - М.: Мир, 1978. $-420 c$.

2. Ситник В.Ф. Імітачійне моделювання / В.Ф. Ситник В.Ф., Н.С. Орленко. - К.: КНЕУ, 1999p. $208 \mathrm{c}$.
3. Резяпов Н. Развитие систем компьютерного моделирования в вооруженных силах США / Н. Резяпов// Зарубежное военное обозрение. - 2007. - №6. - C.17-23.

4. Заруба О.Г. Імітаційне моделювання: досвід збройних сил Франиії / О.Г. Заруба // Сучасні інформаџійні технологій у сфері безпеки та оборони. - 2008. - № 2(2). C. 44-46.

5. Веб-сайт компанії ВАE Systems [Електронний pecypc]. - Режсим достуny: http: // www.baesystems.com

6. Вэй С. Тренажеры позволяют обучать войска эффективному использованию новейшего оборудования [Электронный ресурс]. - Режим доступа: www.armyguide.com/rus/article/article.php.

7. Веб-сайт Федерального наково-виробничого центру ВАТ «НВО «Марс» [Електронний ресурс]. Режим достуny: http: // www.npomars.com.

8. Веб-сайт компанії «Белфортекс» [Електронний pecypc]. - Режим доступy: http://www.belforex.com.

9. Бигдан В.Б., Гусев В.В., Марьянович Т.П., Сахнюк М.А. Становление и развитие имитационного моделирования в Украине / Труды междунар. симпоз. «Компьютеры в Европе. Прошлое, настоящее $u$ будущее». - К.: Феникс, 1998. - С. 182-193.

10. Мазурін О. «Комп'ютерні баталії...» / О. Мазурін // Військо Украӥни. - 2006. - №1. - С.25-28.

11. Пермяков О.Ю. Шляхи інтегрування імітаиійного моделювання у процес оперативної і бойової підготовки Збройних Сил Украӥни / Доповідь на кафедрі інформатизачії штабів. - К.: НАОУ, 2006. - C.17-22.

Надійшла до редакиії 30.09.2009 p.

Рецензент: доктор технічних наук, старший науковий співробітник В.М. Корольов, Академія сухопутних військ імені гетьмана Петра Сагайдачного, Львів.

\section{МИРОВОЙ ОПЫТ И ТЕНДЕНЦИИ ИСПОЛЬЗОВАНИЯ СРЕДСТВ ИМИТАЦИОННОГО МОДЕЛИРОВАНИЯ БОЕВЫХ ДЕЙСТВИЙ}

Р.В.Казмирчук, Е.В.Рыжов, О.В.Королёва, В.И. Боженко

В статье проведен обзор основных принципов применения средств имитачионного моделирования, а также освещена история создания, внедрения и новейшие тенденции развития средств имитационного моделирования для подготовки видов войск (сил) ведущих стран мира. Проанализирован опыт внедрения и дальнейшие перспективы развития средств имитационного моделирования вооружения, боевой техники и применения воинских формирований всех уровней в общей системе боевой подготовки Вооруженных Сил Украины.

Ключевые слова: имитационное моделирование, симулятор, модель, учения с использованием имитационного моделирования, боевые действия.

\section{WORLD EXPERIENCE AND TENDENCIES OF THE BATTLE ACTIONS SIMULATION FACILITIES IMPLEMENTATION}

R.V.Kazmirchyk, E.V.Ryzhov, O.V.Koroleva, V.I. Bozhenko

In the article the review of the modeling and simulation facilities basic principles application is conducted, and also the history of creation, introductions and newest progress of facilities of modeling and simulation trends for the world leading countries troops (forces) types preparation is highlighted. Modeling and simulation facilities of armament, military equipment and application of the all levels military formations in the general system of the combat training of Ukrainian Armed Forces experience of introduction and further prospects of development is analyzed.

Keywords: modeling and simulation, simulator, model, computer assisted exercise, battle actions. 